\title{
Cytauxzoon felis and 'Candidatus Mycoplasma haemominutum' coinfection in a Brazilian domestic cat (Felis catus)
}

\author{
Co-infecção por Cytauxzoon felis e 'Candidatus Mycoplasma haemominutum' \\ em um gato doméstico (Felis catus) no Brasil
}

Leticia Mendes Pupio Maia ${ }^{1}$; Aloysio de Mello Figueiredo Cerqueira²; Daniel de Barros Macieira ${ }^{1}$;

Aline Moreira de Souza ${ }^{1}$; Namir Santos Moreira ${ }^{1}$; Adrianna Vieira da Silva ${ }^{3}$; Joanne Belle Messick;

Renata Fernandes Ferreira ${ }^{1}$; Nádia Regina Pereira Almosny ${ }^{1 *}$

\begin{abstract}
${ }^{1}$ Departamento de Patologia e Clínica Veterinária, Faculdade de Veterinária, Universidade Federal Fluminense - UFF, Niterói, RJ, Brasil
${ }^{2}$ Departamento de Microbiologia e Parasitologia, Instituto Biomédico, Universidade Federal Fluminense - UFF, Niterói, RJ, Brasil

${ }^{3}$ VetLab Análises Clínicas Veterinárias, Petrópolis, RJ, Brasil

${ }^{4}$ Department of Comparative Pathobiology, School of Veterinary Medicine, Purdue University, West Lafayette, IN, USA
\end{abstract}

Received May 22, 2012

Accepted December 21, 2012

\begin{abstract}
This article describes the first detection of Cytauxzoon felis, using molecular techniques, in a naturally infected domestic cat from Brazil, South America. Coinfection with 'Candidatus Mycoplasma haemominutum' was also found. The molecular identification of the piroplasmid species was performed by Polymerase Chain Reaction (PCR) and sequencing analysis. A $284 \mathrm{pb}$ fragment of the gene encoding the $18 \mathrm{~S}$ ribosomal RNA region was amplified and showed 99\% identity with other C. felis strains from North America. In addition, PCR-RFLP (restriction fragment length polymorphism) analysis, which amplifies a $595 \mathrm{bp}$ fragment of the gene encoding $16 \mathrm{~S}$ ribosomal RNA of some bacterial species, identified the co-infecting species as 'Candidatus M. haemominutum'.
\end{abstract}

Keywords: Cytauxzoonosis, hemoplasmosis, PCR, sequencing, feline.

\section{Resumo}

Este artigo descreve a primeira detecção de Cytauxzoon felis em um gato doméstico naturalmente infectado no Brasil, América do Sul, através de técnicas moleculares. Também foi encontrada co-infecção com 'Candidatus Mycoplasma haemominutum'. A deteç̧ão molecular da espécie do piroplasmídeo foi realizada através da reação em cadeia pela polimerase (PCR) e sequenciamento. Um fragmento de $284 \mathrm{pb}$ do gene codificador da regiáo $18 \mathrm{~S}$ do RNA ribossomal do parasito foi sequenciada e mostrou $99 \%$ de identidade com outros isolados de C. felis da América do Norte. Ademais, através da análise por meio de PCR-RFLP (Polimorfismo no comprimento de fragmentos de restrição), que amplifica um fragmento de 595 pb do gene codificador da porção 16 do RNA ribossomal de algumas espécies de bactérias, concluiu-se que a espécie com-infectante era 'Candidatus M. haemominutum'.

Palavras-chave: Cytauxzoonose, hemoplasmose, PCR, sequenciamento, felino.

Cytauxzoon felis, a protozoan parasite that infects domestic and wild felids, was first reported in domestic cats from the United States of America (the USA) in the mid-seventies (WAGNER, 1976). In the USA, bobcats (Lynx rufus) are the natural reservoir hosts for this parasite with high prevalence, but other felids such as Florida panthers (Puma concolor coryi) and domestic cats may also maintain long-term parasitemias and serve as reservoir hosts

\footnotetext{
${ }^{*}$ Corresponding author: Nádia Regina Pereira Almosny

Departamento de Patologia e Clínica Veterinária, Faculdade de Veterinária,

Universidade Federal Fluminense - UFF, Rua Vital Brazil Filho, 64,

Santa Rosa, CEP 24230-340, Niterói, RJ, Brasil

e-mail: almosny@vm.uff.br
}

(SHOCK et al., 2011). Two tick species, Dermacentor variabilis and Amblyomma americanum, are the only known vectors for C. felis in the USA (REICHARD et al., 2009).

In Brazil, natural Cytauxzoon sp. infections have been confirmed by molecular techniques in wild/exotic felids (PEIXOTO et al., 2007; ANDRÉ et al., 2009; FILONI et al., 2012), but few studies regarding natural cytauxzoonosis in domestic cats were solely based on the identification of parasites on blood smears (MENDES-DE-ALMEIDA et al., 2007).

This article describes the first report of $C$. felis natural infection in a domestic cat in Brazil, South America, using molecular techniques (PCR and sequencing analysis). Furthermore, the 
occurrence of 'Candidatus Mycoplasma haemominutum' co-infection was also confirmed by PCR-RFLP (restriction fragment length polymorphism) analysis.

A 5-year-old crossbred domestic cat was taken to a veterinary practice in the municipality of Areal, State of Rio de Janeiro, Brazil, presenting dehydration, vomiting, prostration and anorexia. At the time of admission, blood samples were collected for hematological and serum biochemical analyses: alanine aminotranferease (ALT), aspartate aminotransferase (AST), and Blood Urea Nitrogen (BUN). The animal was also tested for the presence of Feline Immunodeficiency Virus (FIV) antibodies and Feline Leukemia Virus (FeLV) infection using a commercial ELISA kit (Snap FIV Antibody/FeLV Antigen Combo; IDEXX Laboratories, Westbrook, ME, USA). Despite supportive therapy and antibiotics treatment (doxycycline $5 \mathrm{mg} / \mathrm{kg}$, given by oral route every 12 hours), the animal died four days after the onset of symptoms.

Laboratorial findings consisted of neutrophilia with a mild left shift, severe lymphopenia, thrombocytopenia, and increased ALT, AST activities and BUN concentration. Piroplasms within erythrocytes, reactive monocytes and platelet clumps were observed during Giemsa-stained blood smear evaluation. The cat tested negative for both FIV antibodies and FeLV antigen (Snap FIV antibody/FeLV antigen Combo, Idexx Laboratories, Westbrook, ME, USA).

Genomic DNA was extracted from the cat's blood sample using a commercial kit (Illustra Blood Genomic Prep Mini Spin Kit, GE Healthcare, Piscataway, NJ, USA) according to the instructions provided by the manufacturer. Polymerase Chain Reaction (PCR) was performed with primer pair specific for $C$. felis $18 \mathrm{~S}$ rRNA gene, as previously described by Birkenheuer et al. (2006). Both positive (known positive sample gently provided by Dr. Adivaldo Henrique da Fonseca, UFRRJ, RJ, Brazil) and negative (Ultra-Pure DNase/RNase-Free Distilled Water, Invitrogen, Carlsbad, CA, USA) controls were used in each set of reactions The 284 bp DNA fragment was purified using the PureLink PCR Purification Kit (Invitrogen, Carlsbad, CA, USA) and subjected to direct sequencing in both directions. Alignment and sequence analysis were performed using the BioEdit Sequence Alignment Editor 7.0.1 (http://mbio.ncsu.edu/BioEdit/bioedit. html), and the sequence (GenBank Access number JX393072) was compared with different Cytauxzoon spp. sequences available in the GenBank (http://www.ncbi.nlm.nih.gov/genbank/). The alignment of this sequence with other isolates of $C$. felis from North America (AF399930, AY679105, and AY531524) and a captive felid from Brazil (GU903911) showed 99\% nt identity.

A second PCR was performed targeting Mycoplasma spp. 16S rRNA, according to Criado-Fornelio et al. (2003), which amplifies a 618 bp product for 'Candidatus M. haemominutum'. RFLP assay with EcoRI endonuclease was performed and the two fragments obtained (269 and 349 bp) were consistent with 'Candidatus M. haemominutum' infection (Figure 1). Known positive samples containing DNA obtained from $M$. haemofelis and 'Candidatus M. haemominutum'(kindly provided by Dr. Ana Márcia de Sá Guimarães, Purdue University, West Lafayette, IN, USA), and negative - water (Ultra-Pure DNase/RNase-Free Distilled Water, Invitrogen, Carlsbad, CA, USA) controls were also used.

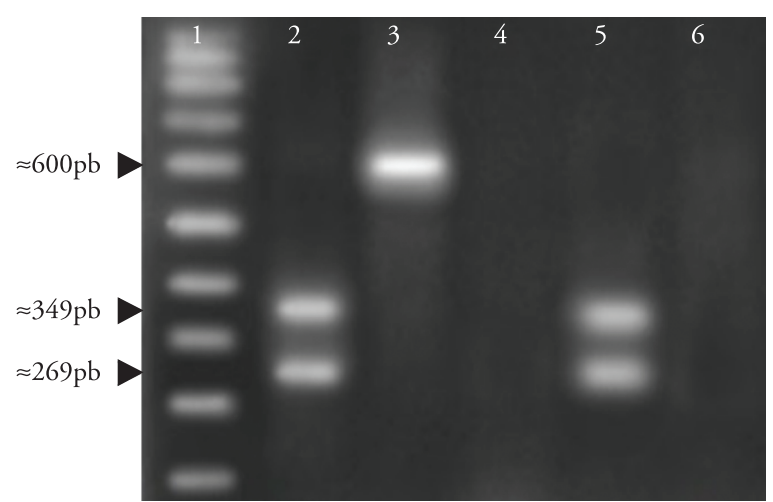

Figure 1. Agarose gel analysis of PCR for hemoplasmas 16S rRNA gene combined with EcoRI digestion results. Line 1 - Molecular weight marker (100 bp ladder; BioTools, Madrid, Spain); line 2 - 'Candidatus Mycoplasma haemominutum' positive control; line 3 - M. haemofelis positive control; line 4 - Hemoplasma negative control; line 5 - 'Candidatus M. haemominutum' positive sample; line 6 - Negative sample.

This is the first report of $C$. felis and 'Candidatus M. haemominutum' natural coinfection in a domestic cat in Brazil. Cytauxzoon felis may cause hematological and clinical chemistry changes in infected cats, according to Meinkoth and Kocan (2005), and some of these changes (neutrophilia, lymphopenia, thrombocytopenia, increased ALT and AST activities and BUN concentration) were observed herein. 'Candidatus Mycoplasma haemominutum' is a hemotrophic bacterial species that can induce anemia in cats - both alone or in combination with other pathogens (BIONDO et al., 2009; SANTOS et al., 2009). In this case, although anemia was not described, the association of both vector-borne organisms may have contributed to the aggravation of the clinical and hematological alterations that resulted in the fatal outcome.

The diagnosis of a domestic cat positive for $C$. felis DNA represents the first report of such infection under natural conditions confirmed by molecular techniques in South America. In Brazil, future research efforts using molecular techniques are needed to study these protozoa natural host(s), vector(s) and pathogenicity.

In addition, infections caused by both $C$. felis and hemoplasmas should be screened when there is suspicion of blood parasites in Brazilian domestic cats.

\section{Acknowledgements}

The authors are grateful to FAPERJ, CAPES and $\mathrm{CNPq}$ for the financial support. We also acknowledge Dr. Adivaldo da Fonseca (Universidade Federal Rural do Rio de Janeiro - Seropédica - RJ - Brazil) for providing Cytauxzoon felis positive control and Dr. Ana Márcia de Sá Guimarães (Purdue University - West Lafayette - IN - USA) for the hemoplasma positive controls.

\section{References}

André MR, Adania CH, Machado RZ, Allegretti SM, Felippe PAN, Silva KF, et al. Molecular detection of Cytauxzoon spp. in asymptomatic Brazilian wild captive felids. J Wild Dis 2009; 45(1): 234-237. PMid:19204356. 
Biondo AW, Dos Santos AP, Guimarães AMS, Vieira RFC, Vidotto O, Macieira DB, et al. A review of the occurrence of hemoplasmas (hemotrophic mycoplasmas) in Brazil. Rev Bras Parasitol Vet 2009; 18(3): 1-7. PMid:19772768. http://dx.doi.org/10.4322/ rbpv.01803001

Birkenheuer AJ, Marr H, Alleman AR, Levy MG, Breitschwerdt EB. Development and evaluation of a PCR assay for the detection of Cytauxzoon felis DNA in feline blood samples. Vet Parasitol 2006; 137(1-2): 144-149. PMid:16417970. http://dx.doi.org/10.1016/j.vetpar.2005.12.007

Criado-Fornelio A, Martinez-Marcos A, Buling-Saraña A, BarbaCarretero JC. Presence of Mycoplasma haemofelis, Mycoplasma haemominutum and piroplasmids in cats from southern Europe: a molecular study. Vet Microbiol 2003; 93(4): 307-317. http://dx.doi. org/10.1016/S0378-1135(03)00044-0

Filoni C, Catão-Dias JL, Cattori V, Willi B, Meli ML, Ramiro Corrêa $\mathrm{SH}$, et al. Surveillance using serological and molecular methods for the detection of infectious agents in captive Brazilian neotropic and exotic felids. J Vet Diagn Invest 2012; 24(1): 166-173. PMid:21908268. http:// dx.doi.org/10.1177/1040638711407684

Meinkoth JH, Kocan AA. Feline cytauxzoonosis. Vet Clin North Am Small Anim Pract 2005; 35(1): 89-101. PMid:15627629. http://dx.doi. org/10.1016/j.cvsm.2004.08.003

Mendes-de-Almeida F, Labarthe N, Guerrero J, Faria MC, Branco AS, Pereira CD, et al. Follow-up of the health conditions of an urban colony of free-roaming cats (Felis catus Linnaeus, 1758) in the city of Rio de Janeiro, Brazil. Vet Parasitol 2007; 147(1-2): 9-15. PMid:17481822. http://dx.doi.org/10.1016/j.vetpar.2007.03.035

Peixoto PV, Soares CO, Scofield A, Santiago CD, Franca TN, Barros SS. Fatal cytauxzoonosis in captive-reared lions in Brazil. Vet Parasitol 2007; 145(3-4): 383-387. PMid:17306459. http://dx.doi. org/10.1016/j.vetpar.2006.12.023

Reichard MV, Meinkoth JH, Edwards AC, Snider TA, Kocan KM, Blouin EF, et al. Transmission of Cytauxzoon felis to a domestic cat by Amblyomma americanum. Vet Parasitol 2009; 161(1-2): 110-115. PMid:19168288. http://dx.doi.org/10.1016/j.vetpar.2008.12.016

Santos AP, Messick JB, Biondo AW, Oliveira ST, Pedralli V, Lasta CS, et al. Design, optimization, and application of a conventional PCR assay with an internal control for detection of 'Candidatus Mycoplasma turicensis' 16S rDNA in domestic cats from Brazil. Vet Clin Pathol 2009; 38(4): 443-452. PMid:19548972. http://dx.doi. org/10.1111/j.1939-165X.2009.00158.x

Shock BC, Murphy SM, Patton LL, Shock PM, Olfenbuttel C, Beringer J, et al. Distribution and prevalence of Cytauxzoon felis in bobcats (Lynx rufus), the natural reservoir, and other wild felids in thirteen states. Vet Parasitol 2011; 175(3-4): 325-330. PMid:21071149. http://dx.doi. org/10.1016/j.vetpar.2010.10.009

Wagner JE. A fatal cytauxzoonosis-like disease in cats. J Am Vet Med Assoc 1976; 168(7): 585-588. PMid:818065. 